\title{
Improving Passing Chest Pass Results Through a Variation Approach to Learning
}

\author{
Windi Naully \\ Post Graduate Program \\ Universitas Negeri Medan, \\ Medan, Indonesia \\ windinaullypjkrcreg@gmail.com
}

\author{
Nurhayati Simatupang \\ Post Graduate Program \\ Universitas Negeri Medan \\ Medan, Indonesia
}

\author{
Tarsyad Nugraha \\ Post Graduate Program \\ Universitas Negeri Medan \\ Medan, Indonesia
}

\begin{abstract}
This study aims to determine the increase in learning outcomes of passing chest passes through a learning variation approach. This type of research is Classroom Action Research. The research subjects were 35 students, consisting of 21 students and 14 students. The research instrument observation sheet and portfolio, data analysis techniques using percentages. The results showed: (1). In the first cycle, $19(54 \%)$ students had finished studying, while the remaining $16(46 \%)$ students had not yet completed. The average value obtained is 75 . (2). In cycle II, there were $27(77 \%)$ completed, while the rest, $8(23 \%)$ had not yet completed study. The average value obtained reached 79 . The conclusion that the results of passing chest pass learning can be improved by the variation learning approach in the XI grade students of Karya Bakti Private High School. Langkat
\end{abstract}

Keyword - passing chest pass, variasi pembelajaran, bola basket.

\section{INTRODUCTION}

learning is the process of acquiring knowledge, which means that learning is the process of gaining knowledge. Learning activities can not be separated in human life because throughout his life humans always learn new things, so he will get new knowledge as well [1]. learning is a process by which a person undertakes to obtain a new change in behavior as a whole, as a result of his own experience in interactions with his environment [2]. Teaching and learning is an educational activity. Educational values color the interaction that occurs between the teacher and students [3].

Based on the results of research observations that have been conducted by researchers namely, teachers open learning is very less where apperception and motivating students are not there, classroom management is not good by the teacher so that many students can not be disciplined when learning takes place and do not involve students in learning so that many students feel get bored and just sit watching other students do chest pass passes, use of methods, styles or variations of teacher learners who are lacking when teaching, where teachers only stick with books and student worksheets only, Presentation of material is not systematic so that many students cannot understand the material delivered.
Variation in teaching and learning activities is a teacher's activity in the context of teaching and learning interaction processes that aim to overcome student boredom, so that in situations of teaching and learning students always show perseverance, enthusiasm, and full participation [4]. Teacher's deeds in the context of the teaching and learning process aimed at overcoming student boredom so that in the learning process students always show perseverance, enthusiasm, and play an active role [5]. The boredom factor caused by the presentation of monotonous teaching and learning activities towards lessons, teachers and schools, it is necessary to have diversity in the presentation of learning activities.

Learning outcomes include cognitive, affective, and psychomotor abilities. The cognitive domain is knowledge ,comprehension, application, synthesis, evaluation. Affective domain is receiving, responding, valuing, organization, characterization. Psychomotor also includes productive, technical, physical, social, managerial, and intellectual skills. Among these three areas the cognitive domain is most valued by teachers at school because it is related to the ability of students to master the content of the lesson.

Next the teacher evaluates the learning outcomes of the student's chest pass. it was concluded that student basketball learning outcomes, especially in passing chest pass material, are still very low. Students are still not able to do a passing chest pass correctly in accordance with basketball competency standards. Student mistakes in passing a basketball chest pass to a friend are possible because students do not understand the technique of holding the ball and posture when passing basketball where students' fingers and palms are stiff, fingers do not open wide when repulsive with the ball, is not exactly in the position that it should be so that the effects of wrong movements, facilities and infrastructure in private high schools work devoted districts. The ranks are somewhat incomplete, the results of passing chest pass learning obtained by XI High School Private Work Bakti students are only about $40 \%$ of the number of students who score above the KKM and $60 \%$ of other students score below the KKM. Minimum completeness criteria $(\mathrm{KKM})$ in these schools is 75. 
One way to improve learning outcomes in basketball passing, especially chest pass material, is by using an appropriate teaching variation approach. This is caused by various factors and one of them is an inefficient learning process wherein learning basketball often encounters many students who do not play an active role in the learning process especially girls who only watch male students playing basketball when basketball subjects take place. Responding to this, the writer tries to do an innovation in the form of research as an effort to improve basketball learning outcomes, especially in passing chest pass material with the application of the learning variation approach in passing learning where the process of learning this passing does not use just one movement but added a movement that does not violate the rules in basketball passing. In this learning process students will be adjusted between the number of balls with students who are learning, and also because of the lack of facilities and infrastructure, basketball will be replaced with volleyball or other large balls. So students individually will have more opportunities to try and practice passing. The availability of learning facilities is one of the driving factors in the smooth learning process at home. With complete learning facilities, it is expected that student learning outcomes will be better [6].

So hopefully this way students will be more motivated in learning the basic techniques of passing chest pass movements in basketball. Thus, the results of learning to pass a basketball chest pass for a student will increase.

\section{METHOD}

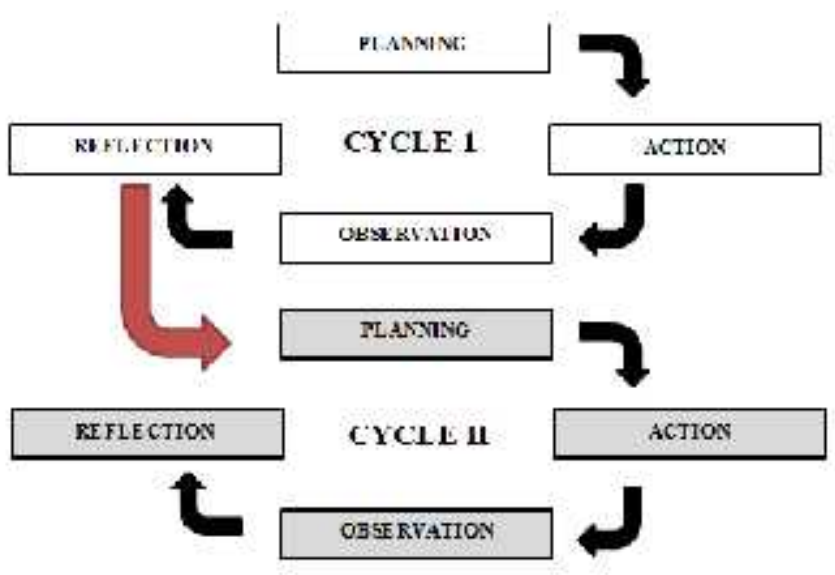

Fig. 1. PTK Research Method

This research uses a CAR approach (Classroom Action Research), Planning: At this stage the teacher and researcher do a scenario in the learning process.

Implementation: the activity to be carried out is to carry out the learning process in the field with the steps of the planned activity. Observation: At this stage the researcher together with the teacher collects data on the learning process and learning outcomes, for further analysis. Reflection: This stage is a means of review actions that have been taken and have been recorded on observation.

The research instrument used in this study was a process assessment with a sheet of forto folio learning outcomes of basketball chest pass and observation sheet.

The subjects of this study were all students of class XI of the Private High School of Bakti District. The number of students consisted of 21 male and 14 female students of 35 students.

\section{RESULTS AND DISCUSSION}

The results of the research data obtained can be seen in the following table below:

TABLE 1. COMPLETE VALUE OF STUDENT LEARNING TEST ON EARLY DATA, CYCLE 1, AND CYCLE II

\begin{tabular}{|c|c|c|c|c|}
\hline \multirow{2}{*}{$\begin{array}{c}\text { Learning } \\
\text { Test Results }\end{array}$} & \multicolumn{2}{|c|}{ Completed Students } & \multicolumn{2}{c|}{$\begin{array}{c}\text { Students who did not } \\
\text { complete }\end{array}$} \\
\cline { 2 - 5 } & $\begin{array}{c}\text { Total } \\
\text { students }\end{array}$ & Percentage & $\begin{array}{c}\text { Total } \\
\text { students }\end{array}$ & Percentage \\
\hline $\begin{array}{c}\text { Preliminary } \\
\text { data }\end{array}$ & 14 & $40 \%$ & 21 & $60 \%$ \\
\hline Cycle I & 19 & $54 \%$ & 16 & $46 \%$ \\
\hline Cycle II & 27 & $77 \%$ & 8 & $23 \%$ \\
\hline
\end{tabular}

From the table above it can be seen that there is an increase in the learning outcomes of students passing chest passes in basketball. In the initial data the number of students who graduated was 14 people with a percentage of $40 \%$ and students who did not pass were 21 people with a percentage of $60 \%$, then in cycle 1 the number of students who graduated was 19 people with a percentage of $54 \%$ and students who did not pass were 16 people with a percentage of $46 \%$. In cycle II the number of students who graduated was 27 people with a percentage of $77 \%$ and students who did not pass were 8 people with a percentage of $23 \%$. 


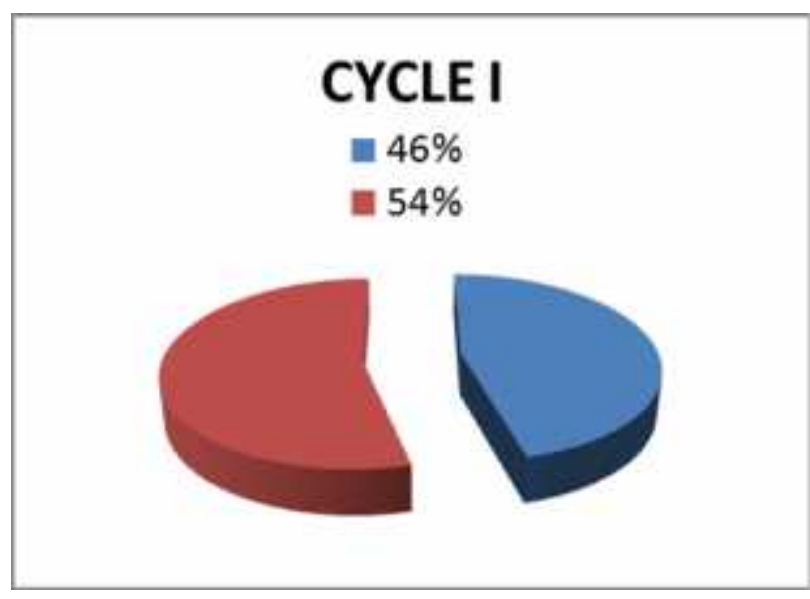

Fig. 2. Cycle 1

Cycle 1 Based on the results of tests conducted on students of Private High School Karya Bakti District. Langkat, There has been an increase of $14 \%$, which was previously $40 \%$ to $54 \%$. This increase occurred after given learning through the variation of learning in passing chest pass material on basketball, there are still difficulties students in learning in the first cycle, namely the lack of understanding of movement correct passing, therefore, it is necessary to improve in cycle II. Here the researchers redesigned the learning activities that had to be improved so that the learning process to be carried out in the second cycle increased.

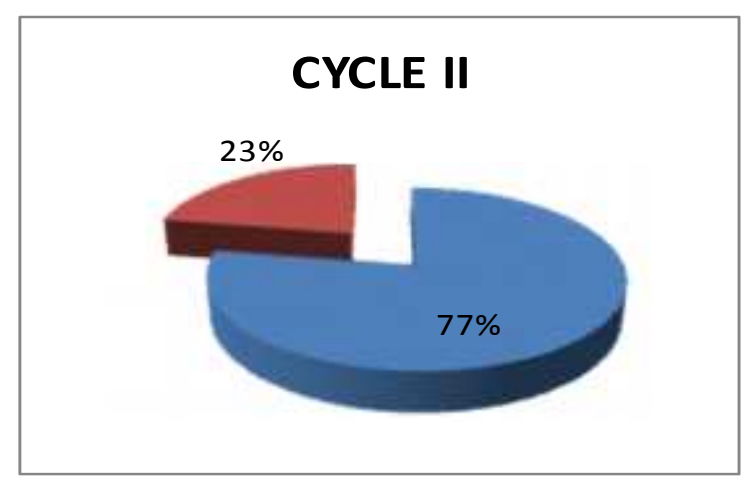

Fig. 3. Cycle II

Cycle II. The results of the test in the second cycle showed better student ability when compared to the first cycle, namely 27 students $(77 \%)$ had achieved mastery learning and still had not achieved mastery learning as many as 8 students 23\%). showed an increase in learning outcomes of basketball chest passes for students, where in this initial attitude students had a better understanding of the correct passing process. Students had bent their knees when they did the initial attitude of basketball chest pass passivation.

In the attitude of the implementation in cycle II also seen an increase that occurred in the results of learning to pass the basketball chest pass of students, where students can already do the right operand leading to the target that is the chest, and also the position of the arms stretched. in cycle II also increased, where some students did the final attitude well, such as after the ball was released from the palm of the hand facing down, fingers pointing at the target, feet in front as a pedestal.

TABLE 2. COMPARATIVE RESULTS OF LEARNING CYCLE I AND CYCLE II

\begin{tabular}{|l|r|c|c|c|c|}
\hline Cycle & $\begin{array}{l}\text { Compl } \\
\text { ete }\end{array}$ & $\begin{array}{l}\text { Percenta } \\
\text { ge }\end{array}$ & Not complete & $\begin{array}{l}\text { Percenta } \\
\text { ge }\end{array}$ & $\begin{array}{l}\text { Average } \\
\text { value }\end{array}$ \\
\hline Cycle I & 19 & $54 \%$ & 16 & $46 \%$ & 75 \\
\hline $\begin{array}{l}\text { Cycle } \\
\text { II }\end{array}$ & 27 & $77 \%$ & 8 & $23 \%$ & 79 \\
\hline
\end{tabular}

The table above shows an increase in student learning outcomes, where in the first cycle students who have finished learning there are 19 students (54\%) and 16 students (46\%) who have not yet finished learning with an average student score of 73. While in the second cycle the increase the number of students completing learning has increased compared to cycle I, namely there are 27 students $(77 \%)$ who have finished learning and 8 students (23\%) who have not yet completed learning, with an average student score of 79 .

\section{CONCLUSION}

The conclusion that the results of passing chest pass learning can be improved by the variation learning approach in the XI grade students of Karya Bakti Private High School. Langkat

\section{REFERENCES}

[1] Suprijono "“Cooperative Learning “, Pustaka Belajar. Yogyakarta, 2010, pp 3.

[2] Daryanto, "Belajar Dan Mengajar", CV Yrama Widya. Bandung, 2010 , pp 2.

[3] Djamarahs.bdanzein "'Strategi Belajar Mengajar", Rineka Cipta. Jakarta, 2002, pp 1.

[4] Uzer Usman, dkk, "Upaya Optimalisasi Kegiatan Belajar Mengajar," PT. Remaja Rosdakarya. Bandung, pp 20.

[5] Hasibuan "Variasi pembelajaran”,Erlangga. Jakarta,2006,pp 46

[6] Dimyanti dan Mudjion, "Belajar Dan Pembelajaran", Penerbit Rineka Cipta. Jakarta, 2006, pp 249. 